\title{
Decreasing the share of nuclear power in energy production in the United States and Germany
}

Szymon GĘBALA, Katarzyna KRYWIAK

DOI: 10.30464/jmee.2019.3.1.61

Cite this article as:

Gębala S., Krywiak K. Decreasing the share of nuclear power in energy production in the United States and Germany. Journal of Mechanical and Energy Engineering, Vol. 3(43), No. 1, 2019, pp. 61-68.

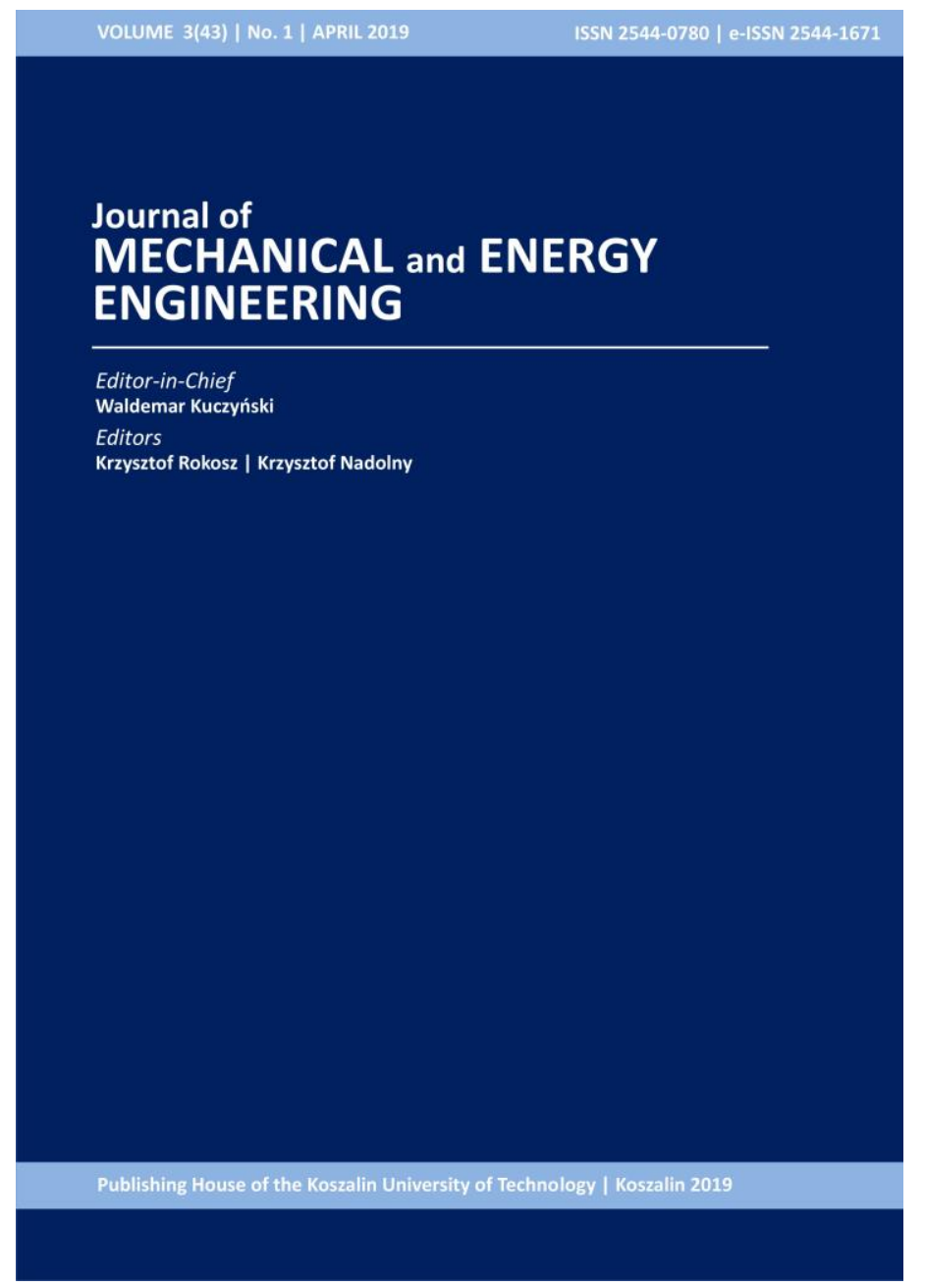

Journal of Mechanical and Energy

Engineering

Website: jmee.tu.koszalin.pl

ISSN (Print): 2544-0780

ISSN (Online): 2544-1671

Volume: 3(43)

Number: 1

Year: 2019

Pages: 61-68

\section{Article Info:}

Received 8 February 2019

Accepted 7 March 2019

\section{Open Access}

This article is distributed under the terms of the Creative Commons Attribution 4.0 (CC BY 4.0) International License (http://creativecommons.org/licenses/by/4.0/), which permits unrestricted use, distribution, and reproduction in any medium, provided you give appropriate credit to the original author(s) and the source, provide a link to the Creative Commons license, and indicate if changes were made. 


\title{
DECREASING THE SHARE OF NUCLEAR POWER IN ENERGY PRODUCTION IN THE UNITED STATES AND GERMANY
}

\author{
Szymon GĘBALA ${ }^{1}$, Katarzyna KRYWIAK ${ }^{2}$ \\ ${ }^{1}$ Faculty of Mechanical Engiering, Mechanics and Machine Construction, Koszalin University of \\ Technology, Raclawicka 15-17, 75-620, Koszalin, Poland \\ ${ }^{2}$ Faculty of Mechanical Engineering, Food Technology and Human Nutrition, Koszalin University of \\ Technology, Raclawicka 15-17, 75-620, Koszalin, Poland, e-mail: krywiakkatarzyna @ gmail.com
}

(Received 8 February 2019, Accepted 7 March 2019)

\begin{abstract}
For long time Germany had many atomic power plants and was important exporter of this nuclear technologies, but right now german government decided to close all their reactors upto 2020. In this presentation we will try to answer for one important question. "Why?", and second one "is it a good idea?". We will try to find out answer for first question and later prove that withdrawing from nuclear energetics is one of the greater mistakes that developed countries are making right now, and please take into consideration that despite the fact $\mathrm{i}$ always believed that right now atomic energy is second to none of what we have right now i carried my research with open mind looking for answers forcing myself to not be biased about subject. Right now I believe in what i believed before, but the change is that now this is not " $i$ think so", but " $i$ know that".
\end{abstract}

Keywords: nuclear energetics, United States, Germany, renewable technologies.

\section{HISTORICAL CONTEXT}

In 1958 world yearly power usage equaled almost $30000 \mathrm{TWh}$, and was believed that this number will rise tenfold up to 2000. Lucky history proven it to be overestimation, and we ended with using around $120000 \mathrm{TWh}$ at the beginning of XXI century, which is "only" quadruped initial value. That is because of much greater efficiency of our ways to make things happen, but that does not change the fact that is still tremendous amount of energy and with time arisen need to create new, more powerful than ever power plants and nuclear energetics for many decades was this answer.

First experimental power plant in Germany was built in 1960 by General Electrics together with Siemens. In the next decades Federal Republic of Germany build 10 next. They were small, with power output not higher than $400 \mathrm{MW}$ (for comparison, greatest modern power plant, located in KashiwazakiKariwa, Japan, generate almost 20 times more energy), and whole nuclear energetics had its "boom" in the $70 \mathrm{~s}$, when we started constructions of big reactors, and also in $70 \mathrm{~s}$ were born anti-nuclear movements. In 1975 construction of nuclear plant was started in Wyhl, Germany. Local populace was strictly against the idea and started strong protest. After two days police used brutal force and whole country was revolved by pictures of policemen dragging farmers and wives through muddy construction site. There was powerful response from public opinion. Few days later local families was supported by great crowd from whole Germany, strong in numbers of 30.000 men and women. Authorities were powerless. Few weeks later construction permit was withdrawn. This success was what made anti-nuclear movement daring and powerful. From now on they were not perceived as extremists and that allowed them to influence politics.

That does not change the fact that they were minority. German nuclear energetics were still on the rise and oil crisis in 1974 only speed up the process and soon german energetics had almost $20000 \mathrm{MW}$ of nuclear power. Later, in 1986 after Chernobyl, leakage in Hamm-Uentrop and riots by nuclear waste recycling plant in Wackersdorf 400 people was wounded. That 
was the moment when Green Party demanded immediate shutdown of all reactors, less extremist groups wanted to do this in period of one decade. After unification of Germany it was decided that all soviet technology based nuclear plants are dangerous and were closed in 1990, and from that moment no more nuclear power plant were built in Germany. Later (1998) formed coalition of SPD and Green Party (both was strongly anti-nuclear) which immediately begun anti-nuclear negotiations with power plant owners. After two years was decided that atomic plants will be closed few years earlier, but there was no force-shutdowns of anything. We can try to guess the influence of project to build gas pipeline on bottom of Atlantic Sea but noteworthy is fact that germany chancellor, after lost elections was hired on very good paid position in Gazprom, which built Northern Pipeline.

In 2005 nuclear physicist Angela Merkel become chancellor, in the beginning it looked like she was pronuclear, but that was not the case. During her government nuclear power production is in almost constant recess and after Fukushima in 2011 trend only sped up. There was no backlash of anti-nuclear movement in Japan, but over $9000 \mathrm{~km}$ was born immediate cross-generational consensus "we do not want nuclear plants in our country" without any consideration to the economic issues of such decision. Hundreds of thousands of protesters left their homes and marched through the streets demanding to withdraw from nuclear energy. German economy is fourth largest in the world and second industrial exporter. It requires cheap energy, and one third of its national production was nuclear based (Figure 1).

With agreement of European Commission from 2007 which requires all Member States to greatly reduce $\mathrm{CO}^{2}$ emission, primary energy usage and increase renewable energetics that is really not easy task, and chancellor Merkel declared that all nuclear plant will be closed by 2020 and 8 of them was closed immediately. As we can see that decision was as far from reason as it can be, and after that carbon and natural gas based energetics gained its renaissance as easiest and cheapest alternatives to power of atom. We do not think that this is necessary to mark its effect on natural environment.

Noteworthy is curvature of fossil fuels and nuclear power usage. That also do not look so bad after 2011 because wind and solar energetics are fast developing fields not favorable circumstances when for $1 / 4$ of the year is cloudy when sun rays have power lesser than $800 \mathrm{Wh} / \mathrm{m}^{2}$ ) and it looks like the Germany can handle this transition despite weaknesses of this policies and as we can see in Figure 2 there is huge increase in usage of natural gas in recent years, but cannot blame them when we look at hard coal and lignite curves, but there is still valid assumption that they would look much better if they would still advance in nuclear power energetics.

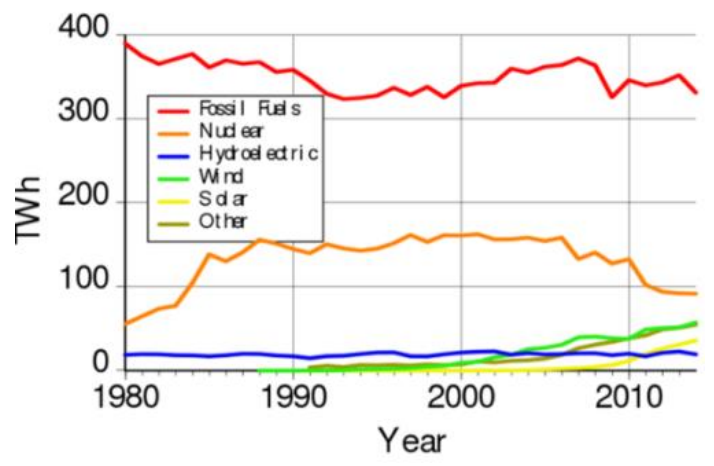

Fig. 1. Electricity production in Germany

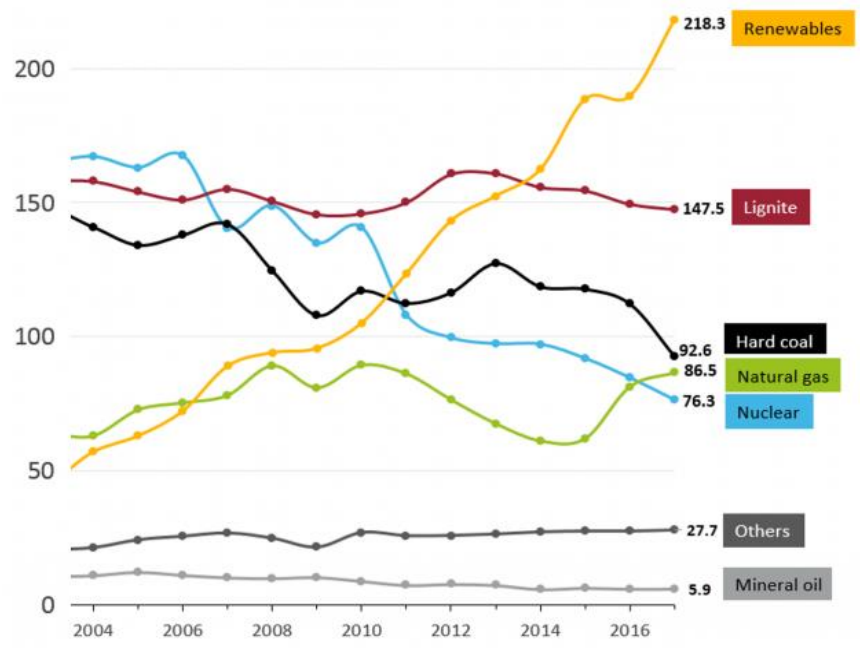

Fig. 2. Gross power production in Germany $1990-2017$, by source 


\section{META-ANALYSIS OF RECENT STUDIES AND DATA AND DISCUSSION}

For many years Germany is becoming "greener and greener" advancing in renewable energy technologies and implementing them into economy. There is still long way ahead of them but we can observe steady growth of renewable energy usage.

If they keep this growth then in XXII century they will absolutely independent of any non-renewable energy source, but this is long time and there are few issues. Today they are still dependent on natural gas from Russia (in 2016, Germany imported 49.8 billion cubic meters of gas from Gazprom) and general energy import from other countries (but they balance that with their own export). Most of its green energy comes from wind as stated on Fig.3, which is highly unreliable source that cannot be planned at length, that is the reason why Germany buys and sells a lot of electrics one time it needs to buy energy, and other to sell. Depending on weather. That do not have to be something wrong per se, but it is hard to believe that whole country with German-like economic power could work purely on unstable energy source.

Answer to that can be biomass. Advancing and possibly powerful branch of technology which is, in full right, treated as renewable and can be expected to provide stable power to country.

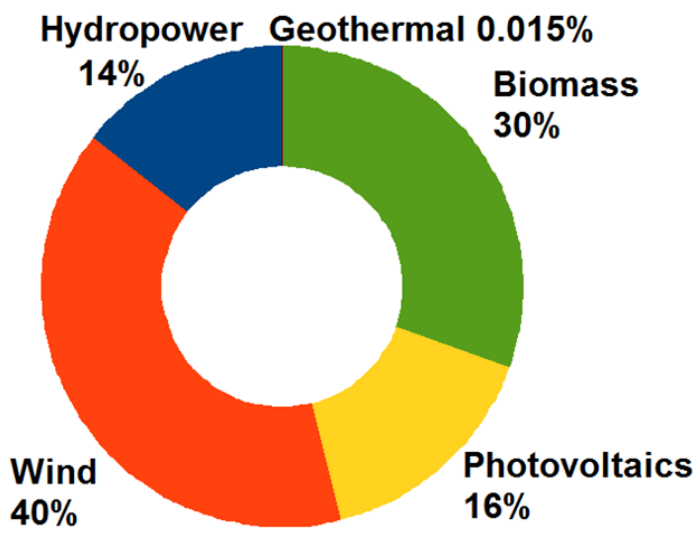

Fig. 3. Green energy in Germany

But with all this assets Germany is still one of the greatest economies in the world and is fifth in coal usage (Fig.5), fifth to eight (depending on the source) in oil consumption (Fig. 6), third (after US and Russia) in natural gas consumption (Fig. 7) and fourteen in renewable energy as percentage of gross energy consumption with value below European Union average (Tab. 1). Considering that, by logic, they are doing great in self-improvement but environment would be grateful if they stayed with nuclear energy for few more decades.

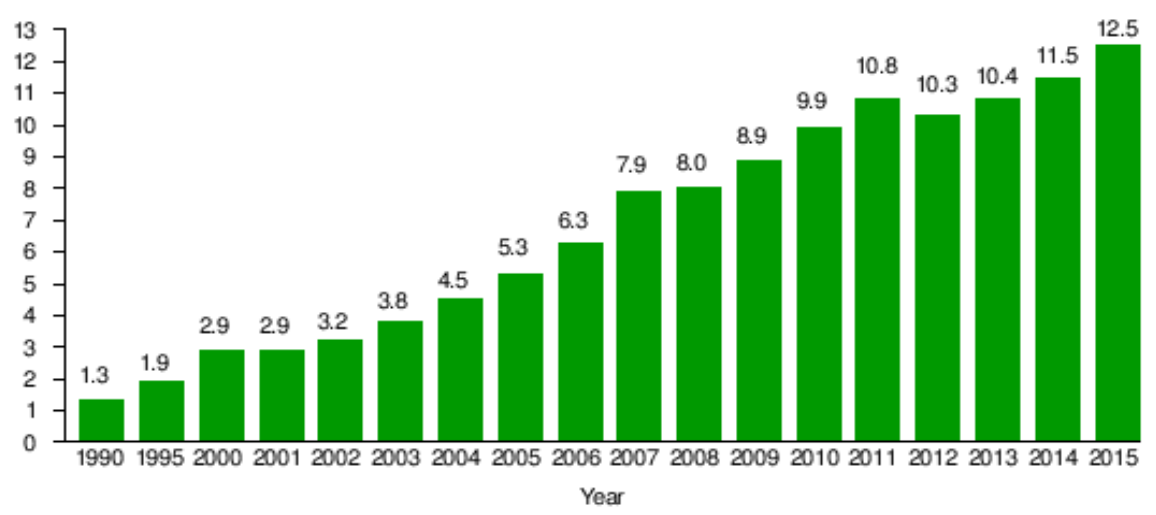

Fig. 4. Growth of renewables as percentage of primary energy consumption in Germany by years 


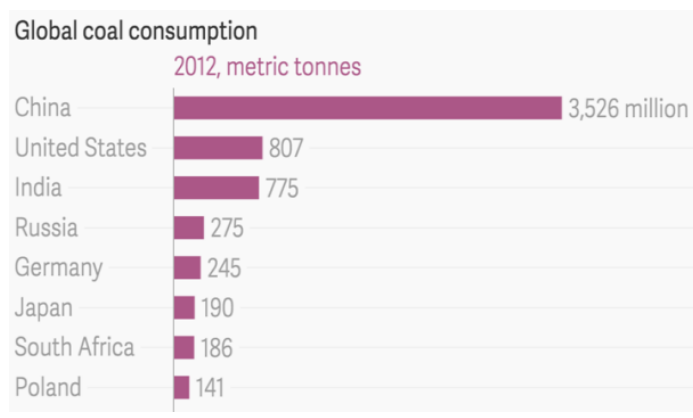

Fig. 5. Coal consumption by countries

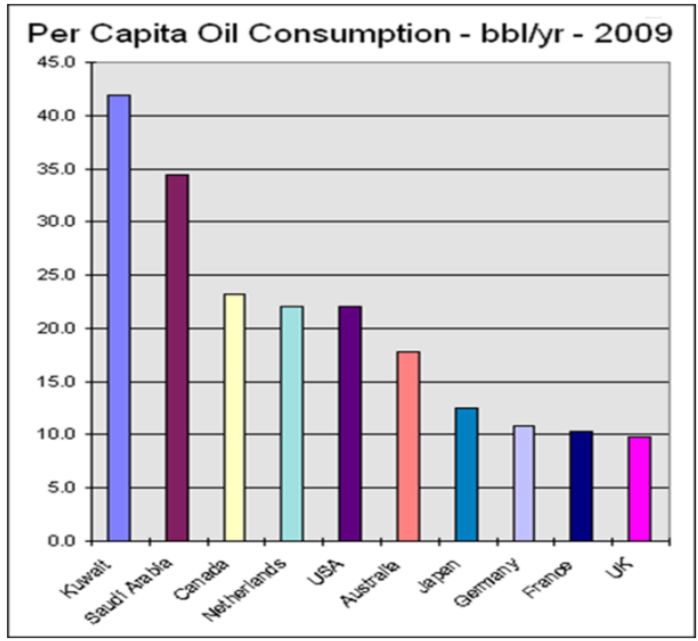

Fig. 6. Oil Consumption by countries

Tab. 1. Percentage of renewable energy in energy by European countries

\begin{tabular}{lll}
\hline Country & 2013 & 2020 target \\
\hline Norway & 65,5 & 67,5 \\
\hline Sweden & 52,1 & 49,0 \\
\hline Lativa & 37,1 & 40,0 \\
\hline Finland & 36,8 & 38,0 \\
\hline Austria & 32,6 & 34,0 \\
\hline Denmark & 27,2 & 30,0 \\
\hline Estonia & 25,6 & 25,0 \\
\hline Romania & 23,9 & 24,0 \\
\hline Bularia & 19,0 & 18,0 \\
\hline Italy & 16,7 & 17,0 \\
\hline Spain & 15,4 & 20,0 \\
\hline EU average & 15 & 20,0 \\
\hline Greece & 15 & 18,0 \\
\hline France & 14,2 & 23,0 \\
\hline Germany & 12,4 & 18,0 \\
\hline
\end{tabular}

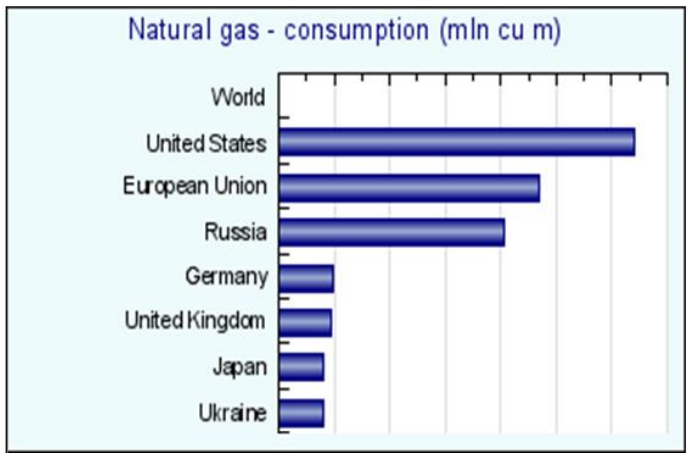

Fig. 7. Natural gas consumption by countries

\subsection{Nuclear Energetics in chosen states of America}

Year 2018. February. America is sustaining polar vortex. Coal stack are frozen. Diesel generators are not enough, and natural gas pipelines are choking as they could not keep with demand. Energy prices are skyrocketing and what happened in Vermont four years in advance? Public opinion forced government to close Yankee Nuclear Plant in Vermont... in the same year inhabitants of Massachusetts opposed building of new pipelines. As effect in 2018 New England survived small energy crisis, but that was not that painful as it could. Because of nuclear power plants in states other than Vermont. In this time atomic power accounted for almost 30\% of energy production. What would happen if similar movement like one in Vermont, forced other power plants to be closed?

Vermont Yankee was fifth greatest power source in whole New England contributing for $4 \%$ of its energy and $70 \%$ of Vermont. When we look at Figure 8 we can see that their hearts are at right place. Shares of energy consumption are shifting from coal and oil to natural gas which is more than two times more efficient when we talk about greenhouse gases by unit of produced electricity, but they are erasing magnificent three decades long progress of constant reducing carbon emission by closing next nuclear power plants (look at Fig.9 and Fig.10).

Note that this will require next 18 years of constant, uninterrupted progress to achieve clean power generation level equal to this that two states have right now. This is long time in which we could advance even more especially when we consider that nuclear energy, when we already have built power plant and infrastructure, is second only to hydroelectricity in term of price and losing that source will definitely have its impact on economics what will make harder for new technologies to develop. 


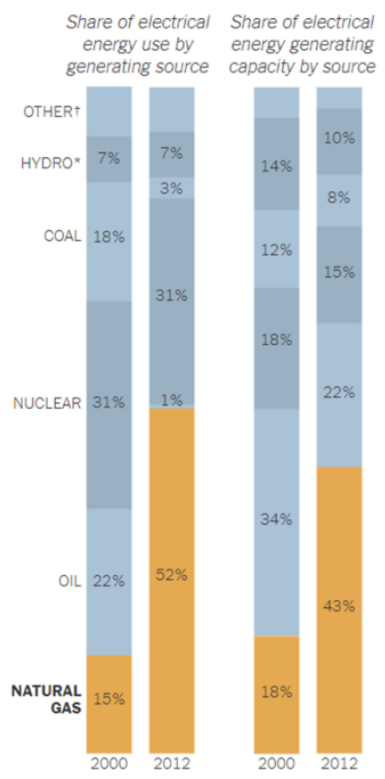

Closing nuclear power plants was supposed to be step to clean energetics (which is really strange argument as nuclear power is widely considered as clean) but we can see on Figure 10 that it was not replaced by solar or wind power, and even not by biomass but almost completely by natural gas which is widely not considered as clean (but it is needed to give it its honor and admit that natural gas is much cleaner than coal or oil).

There is also idea to close nuclear plants at Palo Verde, Arizona. To some degree this can be understandable because Arizona has perfect conditions to generate power from photovoltaic cells, but that is illusory. When we look at Figure 11 and 12 we can clearly see that even in such conditions single nuclear power plant generate $36 \%$ of its energy, which simultaneously is $79 \%$ of its clean energy. This numbers do not make it look good when we think about closing it.

Fig. 8. Energy usage shift in New England between 2000 and 2012

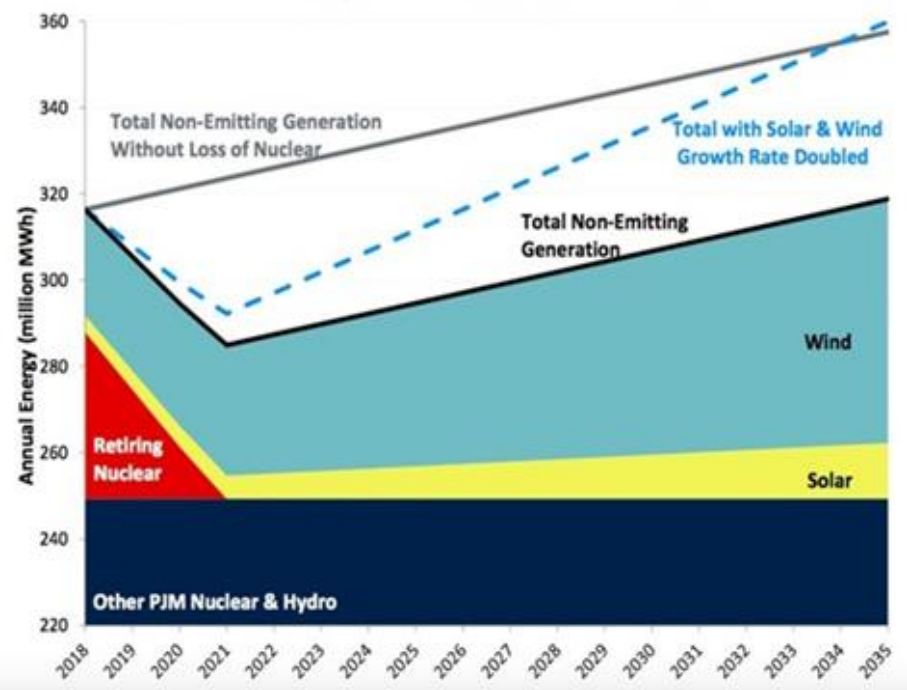

Fig. 9. Expectation of clean energy production in Ohio and Pennsylvania after nuclear power plants retirement

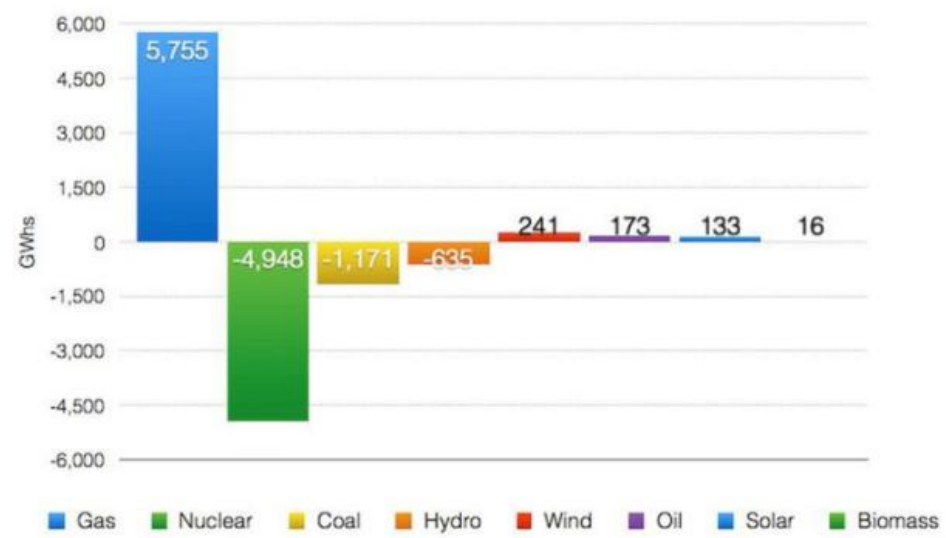

Fig. 10. New England in-state electricity change 2014-2015 


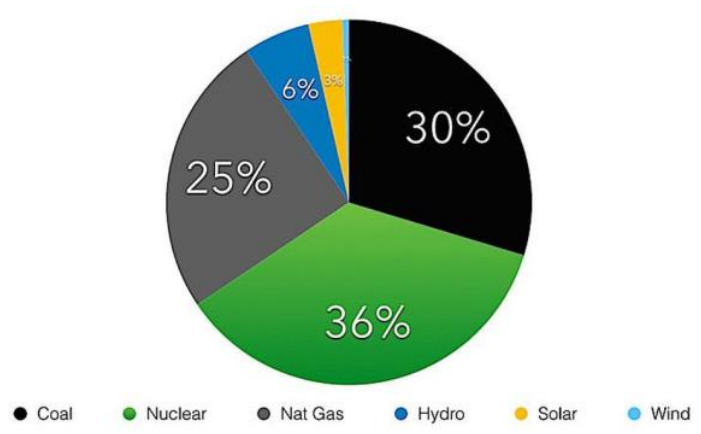

Fig. 11. Shares of Arizona energy production

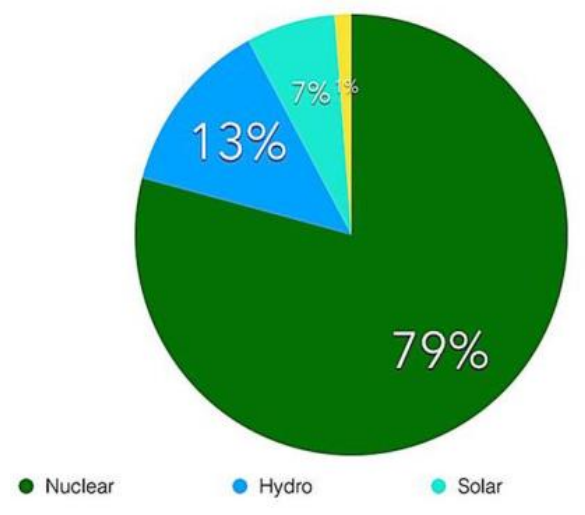

Fig. 12. Shares of Arizona clean energy production

Great part of anti-nuclear movement is fear. Fear about "what will we do with nuclear wastes? They going to radiate for next 50000 years" or "what about deaths in accidents on nuclear plants?" or "Chernobyl", "Fukushima". So let us settle this topics one by one.

First of all, when people say "nuclear wastes that will contaminate earth for next generations" those who did their research knows that today wastes are being reprocessed. Today most commonly used process is called PUREX which stands for Plutonium Uranium Redox EXtraction, this is old hydrometallurgical process (and has story of abuse when in mid $40 \mathrm{~s}$ Hanford Site released to river and air tremendous amounts of radiation in form of iodine-131) but our perspectives are electrometallurgical processes which whilst yet inoperational will allow us to reduce time of used fuel to eradicate to neutral levels in just 3 centuries, which do not seem to be that long period and even when we ignore that we need to stop for the moment and think "what is radiation at all?", and one of possible answers would be "form of energy". Energy that can be used and i believe that we can expect to learn how to use at least part of this energy (and thus reduce deradiationing period) in upcoming decades. Others are afraid of deaths accidents, but this is story just like with bird and swine flu few years ago when new strain emerged and everyone panicked without listening to expert convincing that this strain is less infectious and less severe than classic flu but nobody cared. Media only listened to this few deaths caused by this particular strains. There is the same situation with nuclear energetics. Anti-nuclears movement says only about people who died in accidents on nuclear plants but they give raw data. Without context, and when we look at data at Tab. 2 we can be astonished.

Tab. 2. Mortality rate in energetics by power source

\begin{tabular}{ll}
\hline Energy source & $\begin{array}{l}\text { Mortality rate } \\
\text { (deaths/PWh) }\end{array}$ \\
\hline Coal (global) & 100,000 \\
\hline Coal (US) & 10,000 \\
\hline Oil & 36,000 \\
\hline Natural Gas & 4,000 \\
\hline Biofuel/biomass & 24,000 \\
\hline Solar - rooftop & 440,00 \\
\hline Wind & 150 \\
\hline Hydro (global) & 1,400 \\
\hline Hydro (US) & 5 \\
\hline Nuclear (global) & 90 \\
\hline Nuclear (US) & 0.1 \\
\hline
\end{tabular}

Numbers are clear. Nuclear energetics is clearly most safe way to create energy if we measure that in human lives. And what about Chernobyl and Fukushima? First of them was stupid accident. Soviets were doing tests, and turned off safeties. All of them. That was literally result of them not knowing what they were doing. Ergo: this is highly doubtful to recognize it as representative case. On the other hand something like that cannot be said about Fukushima, but that has to be remembered that its reactor meltdown was caused by tsunami, so there is one moral that should be acknowledged as common truth to not build power plant in area where tsunami, earthquake, tornado or any other natural disaster can destroy it. Japan is specific and cannot really eliminate this dangers, but US and Germany (which are main subject of this paper) can, so tragedy in Fukushima cannot be considered as good reason to close nuclear plants in those two countries.

\section{CONSLUSIONS}

The carried out meta-analysis of data and recent researches about decreasing share of nuclear energetics in United States and Germany prove that this was doubtful method to achieve greener or safer energetics. It must be, however, noticed that Germany and chosen states of USA are doing progress toward 
renewable energetics and do not forsake environment. Parallel to regress made by withdrawal from nuclear power they are still increasing significance of other green ways of gaining energy in ecological and clean manner.

Parameters and structures of national energetics during past years in the mentioned countries prove, without doubt, that nuclear energetics is not more dangerous than competing energy sources as coal and opposition against it lacks solid foundation and is mostly based in subjective emotions and fear, not facts.

Our reachable deposits of coal, oil, natural and shale gas combined matches $1 / 15$ of reachable deposits of uranium if we count them by units of energy. Renouncing power of atom seems like madness in times when every few years we hear about ending stocks of oil (which is used as argument to increase its prices) or nearing energy crisis. If any of this predictions will eventually come true we will be forced to use nuclear energy, but that is something that future generations will have to deal with.

\section{References}

1. Achilles M., Elzey D. (2013) Environmental Sustainability in Transatlantic Perspective. Palgrave Macmillan UK.

2. Amelang S., Wettengel J.(2018): Germany's dependence on imported fossil fuels.

3. Conca J., How Deadly (2012) Is Your Kilowatt?. Forbes.

4. Conca J. (2016) Natural Gas -- Not Renewables -- Is Replacing Nuclear Power. Forbes.

5. Desbrosses N. (2011) World Energy Expenditures.

6. Glasstone S. (1958) Podstawy Techniki Reaktorów Jadrowych. Państwowe Wydawnictwo Naukowe.

7. Mez L. (2012) Piening A., Phasing-Out Nuclear Power Generation in Germany: Policies, Actors, Issues and Non-Issues. Sage Journals.

8. Muchin K.N. (1978) Doświadczalna fizyka jądrowa. Wydawnictwa Naukowo Techniczne.

9. Pach-Gurgul A. (2012) Jednolity rynek energii elektrycznej $w$ Unii Europejskiej $w$ kontekście bezpieczeństwa energetycznego Polski. Diffin.

10. Stacy F. (2016) The levelized cost of electricity from existing generation resources. Institute for Energy Research.

11. Ślifierz J., Ślifierz M. (2014) Niemiecka energetyka jadrowa, czyli wejście $i$ wyjście. CIRE.

12. Wacławek M. (2015) Ogniwa Stoneczne. Wplyw środowiska naturalnego na ich pracę. WNT.

13. https://www.euractiv.com/section/energy/infographic/inf ographic-can-germany-s-energiewende-ensure-supplysecurity/ (access: May 2018).

14. https://www.eia.gov/electricity/annual/html/epa_08_04.h tml (access: May 2018).

15. https://www.forbes.com/sites/jamesconca/2018/04/18/nu clear-power-under-attack-again-this-time-from-theballot-

https://www.cleanenergywire.org/sites/default/files/style s/lightbox_image/public/images/factsheet/germanenergy-sources-import-dependency.png?itok $=\mathrm{dS} 1 \mathrm{q} 3 \mathrm{c} 0 \mathrm{M}$ (access: May 2018).

16. https://www.cleanenergywire.org/sites/default/files/style s/lightbox_image/public/images/factsheet/germanenergy-sources-import-dependency.png?itok=dS1q3c0M (access: May 2018).
17. https://www.theatlas.com/charts/Nya6gW4s (access: May 2018).

18. http://www.gswindell.com/temp7.gif (access: May 2018).

19. http://chinalist.ru/facts/index.php?p_lang=1\&p_param $=6$ 2 (access: May 2018).

20. https://www.nytimes.com/2014/07/11/business/energyenvironment/new-england-confronts-surging-demandfor-natural-gas.html (access: May 2018).

21. http://isonewswire.com/updates/2014/1/28/new-englandgovernors-announce-proposal-to-expand-regional-e.html (access: May 2018).

22. http://www.world-nuclear.org/informationlibrary/nuclear-fuel-cycle/transport-of-nuclearmaterials/japanese-waste-and-mox-shipments-fromeurope.aspx (access: May 2018)

\section{Biographical notes}

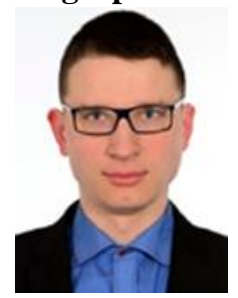

Szymon Gębala is student of sixth semester of Mechanics and Machine Construction on Mechanical Engineering Faculty from Koszalin University of Technology. Since second year firm receiver of chancellor's scholarship for most talented students. His interests focus on computer aids and programming.

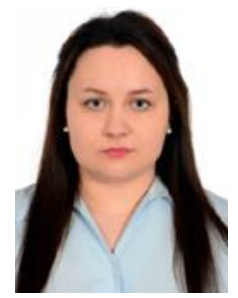

Katarzyna Krywiak is student of sixth semester of Food Technology and Human Nutrition on Mechanical Engineering Faculty from Koszalin University of Technology. Since second year firm receiver of chancellor's scholarship for most talented students. 
